\title{
Influence of Genotype, Salinity, Sulfur Treatments and Planting Container Size on Growth, Yield and Incidence of Gray Mold in Broccoli Plants with Propolis Extract as Disease Control Treatment
}

\author{
Mohamed W. M. Elwan ${ }^{1}$; Khalid E. Abd El-Hamed ${ }^{1}$ and Mohamed I. I. Khalil ${ }^{2}$ \\ ${ }^{1}$ Department of Horticulture, Faculty of Agriculture, Suez Canal University, Ismailia, Egypt \\ ${ }^{2}$ Department of Agricultural Botany, Faculty of Agriculture, Suez Canal University, Ismailia, Egypt
}

Received: 4/6/2017

\begin{abstract}
A pot experiment was conducted at the Experimental Research Farm, Faculty of Agriculture, Suez Canal University, Ismailia in Fall 2013 till Spring 2014. The experiment included two broccoli genotypes ("Sultan" and "Marathon"), two levels of salinity treatments $(0,100 \mathrm{mM} \mathrm{NaCl})$, two levels of sulfur $(0,3 \mathrm{~g} / \mathrm{L}$ soil) and two different soil volume containers $(2,4 \mathrm{~L})$, in split-split plot design. The objective was to investigate the impact of genotype, salinity, sulfur treatments and container size on plant growth, yield and incidence of gray mold in broccoli. In addition, the effect of propolis extract as a natural mean of disease control was also explored. The results of the experiment revealed that broccoli genotypes differed in their growth and yield response. Also, salinity treatment adversely affected the growth and yield of broccoli in both genotypes and sulfur treatments were not able to mitigate the unfavorable effects of salinity on broccoli plants. As a result of this experiment, gray mold in broccoli was reported for the first time in Egypt and the fungus was identified as Botrytis cinerea based on mycological characteristics. Broccoli genotypes showed different disease severity as "Marathon" cv. was highly susceptible, while "Sultan" cv. showed higher degree of resistance. RAPD analysis identified some specific DNA fragments discriminating between the two genotypes which can explain the different response of both genotypes for yield and disease incidence. Salinity treatment significantly increased the disease severity by an average of $15.6 \%$ and $21.2 \%$ when compared to the control for plants grown in large and in small culture container, respectively, which demonstrate the effect of container size on the disease response as the larger size promoted the disease severity. Sulfur application was the most effective treatment in decreasing disease severity by $100 \%$ in both genotypes and in both container sizes. In presence of salinity, the inhibitory effect of sulfur sustained in "Sultan" cv., while sulfur decreased the disease severity in "Marathon" cv. only by $52.5 \%$. In addition, propolis extract displayed inhibitory effect on Botrytis cinerea growth in both genotypes. Overall, genotypic differences observed for yield and salinity tolerance suggest that breeding programs to enhance such important traits are feasible. Soil-supplied sulfur enhanced broccoli defense to disease and can be suggested as mean of managing nutrition to control plant diseases. Finally, propolis extract can be suggested as a natural mean of gray mold disease control in broccoli.
\end{abstract}

Keywords: Botrytis cinerea, gray mold, Brassica oleracea var. italica, salinity, propolis extract, sulfur, container size

\section{INTRODUCTION}

Broccoli (Brassica oleracea var. italica) is a cruciferous crop that is an excellent source of vitamin $\mathrm{C}$, calcium, magnesium, carotenoids, and fiber (Kurilich et al., 1999). Broccoli has received particular attention as the best source of glucosinolates, sulfur-containing compounds, which have been shown to possess health benefits (Fahey et al., 2002). Glucosinolate hydrolysis products could help prevent cancer by enhancing the elimination of carcinogens before they can damage DNA and high intakes of cruciferous vegetables including broccoli have been associated with lower risk of cancer in some epidemiological studies (van Poppel et al., 1999).

Genotypes of plants vary widely in their qualitative and quantitative traits, however, visible plant morphological variation is known to occur at a much lower frequency than at the DNA level (Evans et al., 1984) and as a result, it is necessary to examine for potential variation at the molecular level (Donini et al., 2000). Molecular techniques are valuable tools used in the analysis of genetic materials. Random amplified polymorphic DNA (RAPD) markers provide an efficient technique for polymorphism that allows rapid identification of specific DNA fragments. The use of

Corresponding author e-mail: khalidegy1@yahoo.com
RAPD markers is especially beneficial to discriminate between materials that are genetically similar and to evaluate genetic variability (Bernardo Royo and Itoiz 2004). Identically banding patterns (monomorphism) of the RAPD profiles obtaining from different genotypes suggest similar characteristics while bands unique to one genotype (polymorphism) demonstrate genetic variation. RAPD markers were used to discriminate among cultivars of cabbage (Cansian and Echeverrigaray, 2000), broccoli (Hale et al., 2006), broccoli and cauliflower (Hu and Quiros, 1991), and oilseed rape (Lee et al., 1996).

When a RAPD marker show complete linkage to resistance gene, then the polymorphic RAPD fragment should be cloned and sequenced, followed by designing and synthesizing specific primers that produce an amplification product only in the resistant plants. This specific marker allows a reliable and rapid germplasm screening for resistance in breeding programs to produce elite genotypes (Michelmore, 1995; Waugh, 1997). RAPD was successfully used to develop markers linked to downy mildew resistance in broccoli (Agnola et al., 2000; Farinhó et al., 2000; Giovannelli et al., 2002).

Soil fertility is adversely affected by salinity which has emerged as one of the most serious factors 
limiting plant growth and productivity (Türkan and Demiral, 2009). The loss in plant productivity due to salinity is a consequence of imbalance in ionic and nutrients contents concentration and osmotic effects (Ashraf, 2009) resulting in the production of reactive oxygen species (ROS). Any adaptation that regulates ROS generation in plants will provide efficient defense mechanism for salinity tolerance (Hasegawa et al., 2000; Munns and Tester, 2008). Sulfur is increasingly being recognized to have potential in modulating salinity stress response (Nazar et al., 2011).

Recently, the role of sulfur in plant nutrition has changed and currently sulfur has become one of the most limiting nutrients in agricultural products (Eriksen et al., 2004). Nitrogen and sulfur are the only two fertilizer elements that are constituents of amino acids and subsequently proteins and enzymes. Biswas and Tewatia (1991) indicated that most crop species have higher yield and better quality products when there is an abundant amount of sulfur available in the soil. Elwan and Abd El-Hamed (2011) indicated that sulfur-treated broccoli plants produced higher yield comparing to nontreated plants and the response was more pronounced in genotype "Marathon" than genotype "Sultan". Plants assimilate inorganic sulfur into methionine (Nicoforova et al., 2003), the precursor for glucosinolate production (Moreno et al., 2006). The importance of an adequate supply of sulfur for glucosinolate synthesis has been well documented (Mailer, 1989; Kim et al., 2002). Many of the breakdown glucosinolate products have been implicated in the interaction between Brassica plants and their pests and pathogens due to their role in defense mechanisms (Mithen, 1992; Rosa et al., 1997).

Varying container size alters the root volume of the plants, which can significantly influence plant growth. The main effect of decreased container size is that it increases root restricting conditions (NeSmith and Duval, 1998). Plants experience many physiological and morphological changes in response to reduced rooting volume. Root restriction and container size can impact root and shoot growth, biomass accumulation, photosynthesis, leaf chlorophyll content, flowering and yield. Reduced plant biomass under root restricting conditions could possibly be due to a lower photosynthetic rate (Ruff et al., 1987).

The fungicidal effect of foliar-applied sulfur has been exploited long time ago. In comparison, the significance of soil-applied sulfur for disease resistance only became evident recently. Elemental sulfur has been used efficiently against infections of grapes by powdery mildew (Uncinula necator). In addition to the direct fungicidal effect of foliar-applied sulfur, there was a nutrient-based effect of soil-applied sulfur that resulted in a lower rate of leaf and grape infection and producing a significantly higher yield compared with controls (Bourbos et al., 2000).

Botrytis cinerea and other Botrytis species are important pathogens of numerous plants including vegetables, orchard crops, ornamental plants and stored agricultural products (Jarvis, 1977; Elad et al., 2007). Botrytis cinerea is a common fungus that damages leaves, flowers, stems, fruits and other parts of many plants (Ellis,
1971). Botrytis often attacks very new seedlings, especially if the soil is highly fertilized. It often starts on the leaves as brown spots or patches which change into a grayish furry mould (Williamson et al., 2007). In particular, young plants keel over and die very quickly once affected. Conditions that encourage moulds are over-watering, overcrowding and over-feeding.

Propolis is a resinous hive product collected from plant buds by bees and its color range from green to dark brown according to plant source. Bee products such as honey, pollen and propolis are used for the treatment of several diseases. It is believed that propolis can be used as a perfect antibiotic agent (Cherbuliez, 1996; Feraboli, 1996; Grange and Davey, 1990; Schmidt and Schmidt, 1996). Investigations have indicated that propolis contains wax, flavonoids, amino acids, essential oils, pollen, minerals and organic matters (Walker and Crane, 1987; Crane, 1990; Scheller, 1990). There has been considerable emphasis on the studies involving propolis (Crane, 1990; Ghisalberti, 1979; Yamauchi et al., 1992). It was established that flavonoids, benzoic acid, and derivatives found in propolis showed antibiotic, antiviral and antimycotic effect.

The objective of this study was to investigate the effect of salinity, sulfur treatment and container size on plant growth, yield and incidence of gray mold in two broccoli genotypes. Moreover, the influence of propolis extract as a natural mean of the disease control was also studied.

\section{MATERIALS AND METHODS}

\section{Experiment set up}

Seeds of broccoli were sown in 209-cell styrophom trays under greenhouse condition in late October 2013. Broccoli genotypes were "Sultan" (Asgrow Seed Company, USA) and "Marathon" (Sakata Seed America Inc., USA). The trays were filled with a mixture of peatmoss and vermiculite $1: 1(\mathrm{v} / \mathrm{v})$ enriched with different nutrients. After emerging, they were watered with a commercial nutrient solution (19-19-19 N-P-K with micronutrients) at a dilution of 1:200. The seedlings were maintained under mean temperature of $29^{\circ} \mathrm{C}$. The 5 weeks old transplants were moved to black plastic bags in early December 2013 and the experiment was terminated in mid March 2014. Half of the plants were planted in small size plastic bags (2 liter of soil) while the other half were planted in larger size bags (4 liter of soil). The soil was sandy soil $(85.2 \%$ sand, $11.5 \%$ silt and $3.3 \%$ clay) with $\mathrm{pH}=8.27$ and electrical conductivity $(\mathrm{EC})=0.47 \mathrm{dSm}^{-1}$. Broccoli plants were treated with salty solution at the concentration of 0.0 and $100 \mathrm{mM} \mathrm{NaCl}$ twice weekly after one month of transplanting. Small culture bags were irrigated with $200 \mathrm{ml}$ of nutrient solution (19-19-19 N-P-K with micronutrients) plus the salt solution while the larger bags were irrigated with $400 \mathrm{ml}$. Sulfur was applied to the soil at the rate of 3 grams for each liter of soil in the plastic bag and the amount was divided to 3 doses. The first dose was added after one month of transplanting while the second and third doses were applied after two weeks intervals. 
The experiment was laid-out in split-split-split plot in randomized complete block design (RCBD) with three replicates. The experiment employed two genotypes ("Sultan" and "Marathon") in the main plots, two different soil volume containers (2 and $4 \mathrm{~L}$ ) in the sub-plots, two levels of salinity treatments $(0.0$ and 100 $\mathrm{mM} \mathrm{NaCl})$ in split-split plots and two levels of sulfur $(0$ and $3 \mathrm{~g} / \mathrm{L}$ soil) in split-split-split plots in an orthogonal fashion.

Fresh weight of curds was recorded on all plants in the experimental unit and then dried in forcedair oven at $70^{\circ} \mathrm{C}$ for $72 \mathrm{~h}$ to obtain the dry weight. Fresh weight of vegetative growth was recorded after the harvest of the curd of the plant. Both curd dry weight (\%) and plant dry weight (\%) were calculated according the following formula: [(Fresh Weight- Dry Weight)/Fresh Weight]x100.

\section{Pathogenicity test}

Pathogenicity of Botrytis sp. was tested on two broccoli genotypes "Sultan" and "Marathon". The two genotypes were planted in the winter of 2013. Young healthy leaves were excised, washed, and placed on moist paper towels in plastic trays (with 5 leaves per tray spaced at about $5 \mathrm{~cm}$ between leaves). Mycelial agar plugs (6 mm diameter) of Botrytis sp was removed from the colony margin of a 2-day-old PDA culture $\left(18^{\circ}\right.$ C), and one plugs was inoculated face down on each leaf. For the control treatment, one uncolonized PDA plugs were inoculated on each leaf. There were five trays (replicates) for each genotype. After incubation at $20^{\circ} \mathrm{C}$ under the regime of 12 -h light/12-h dark for 3 days, lesion length that developed at each inoculation site was measured after $24 \mathrm{~h}$. and $72 \mathrm{~h}$.

\section{Disease severity}

After 20 days from sowing, the young plants inoculated with $\left(1 \times 10^{6}\right)$ spores per $\mathrm{ml}$ by dropping 1 $\mathrm{ml}$ of inoculation on the young leaves according to Chen and Wang (2005). The plants were covered with plastic bags for one day to maintain enough moisture to induce the conidia to infect the plants. Disease severity index (DSI) was determined after 34 days from the sowing using the formula: $\mathrm{DSI}=\sum$ (rating of each plant)/4 (number of plants rated) (Bussey and Stevenson, 1991) where, 0: no symptoms, 1: 1 - 24\% leaf area infected, 2: $25-49 \%$ leaf area infected, 3: 50 $-75 \%$ leaf area infected and 4: $76-100 \%$ leaf area infected.

\section{Application of propolis extract against Botrytis cinerea}

Propolis was collected from bee hives in Ismailia, Egypt in April 2014. Czapek - Dox agar was used as main medium throughout the study. The used propolis was extracted with hot water. Water extracts $(0.1,0.2$ and $0.3 \%)$ of propolis were prepared. Medium was separately prepared in each water extract, after which a $120 \mathrm{ml}$ of media were dispensed into $250 \mathrm{ml}$ Erlenmeyer flasks and sterilized by autoclaving at $121^{\circ}$ $\mathrm{C}$ for $15 \mathrm{~min}$.

\section{Assessment of inhibition of fungal growth}

The effect of propolis at different concentrations $(0.1,0.2$ and $0.3 \%)$ was determined against the growth of $B$. cinerea. Medium was dispensed into each Petri plates as $10 \mathrm{ml}$. Five $\mathrm{mm}$. discs of the test fungi were cut from periphery of 7 days old cultures, inoculated upside down separately onto each assay plate and incubated at $20^{\circ} \mathrm{C}$. The colony diameter was measured and mycelia inhibition percentage was calculated following Deans and Svoboda (1990). Three replicates of each treatment were similarly maintained and then averages have been calculated. Control sets were simultaneously run without using propolis. On the other hand, the effect of propolis at different concentrations $(0.1,0.2$ and $0.3 \%)$ was determined against sclerotia germination of $B$. cinerea. The sclerotia were dipped in propolis of each concentration and the sclerotia were inoculated in the plates including the Czapek-Dox agar medium. Each plate included 3 sclerotia of the test fungi, and plates were incubated at $20^{\circ} \mathrm{C}$. The percent of sclerotia germination was calculated. Ten replicates of each treatment were similarly maintained and averages have been calculated.

\section{Percentage of Inhibition $=(\mathrm{C}-\mathrm{T} / \mathrm{C}) \times 100$}

\section{Where;}

C: Colony diameter of mycelium from control Petri plate (mm.)

$\mathrm{T}$ : Colony diameter of mycelium from test Petri plate $(\mathrm{mm}$.

\section{Genomic DNA isolation, PCR reaction and RAPD analysis}

DNA of the two tested broccoli genotypes was extracted from the recent leaves of the plants as described by Murray and Thompson (1980). Small pieces $(0.5 \mathrm{~g})$ of leaf tissue were frozen in liquid nitrogen in Eppendorf tubes and homogenized in $500 \mathrm{ml}$ of extraction buffer ( $2 \%$ CTAB, $1.4 \mathrm{~m} \mathrm{NaCl}, 20 \mathrm{mM}$ EDTA pH 8.0, 100 mM Tris-HCl, pH 8.0, $0.1 \mathrm{~m}$ BMercato ethanol). The extract was incubated at $60 \mathrm{C}^{\circ}$ for $20 \mathrm{~min}$. to this, $500 \mathrm{ml}$ of phenol : chloroform : isoamyl alcohol (24:24:1) were added and mixed by vortexing for $30 \mathrm{sec}$. followed by centrifugation at $10,000 \mathrm{~g}$ for $5 \mathrm{~min}$. at room temperature.

The aqueous phase was transferred to another tube. This was once again extracted with $500 \mathrm{ml}$ of chloroform: isoamyl alcohol (24:1) in Eppendorf tubes. To the aqueous phase, 0.6 volume of isopropanol was added, precipitated the genomic DNA and spooled the fibrous DNA. Genomic DNA was then washed three times with $70 \%$ ethanol, dried in vacuum, dissolved in TE containing $10 \mathrm{mg} / \mathrm{ml}$ RNase and incubated at $37 \mathrm{C}^{\circ}$ for $30 \mathrm{~min}$. followed by extraction with phenal: chloroform: isoamyl alcohol and the aqueous phase was transferred to a fresh tube. The genomic DNA was then precipitated by adding $0.3 \mathrm{M}$ sodium acetate, $\mathrm{pH} 5.2$ (final concentration) and 2.5 vol. of ethanol and collected by centrifugation at $10.000 \mathrm{x}$ g for $20 \mathrm{~min}$. at $4^{\circ} \mathrm{C}$. The pellet was washed with $70 \%$ ethanol, vacuum dried and dissolved in TE.

Ten random oligonucleotide (10 mer) primers (Laboratories of the Midland Certified Reagent Company Inc. Texas, USA) were tested for use in RAPD analysis and their sequences are presented in Table (1). 
Table (1): The nucleotide sequence of primers used in the RAPD analysis

\begin{tabular}{ll}
\hline Primer & Nucleotide Sequence \\
\hline A01 & 5'CAGGCCCTTC3' \\
A02 & 5'TGCCGAGCTG3' \\
$\mathbf{A 0 3}$ & 5'AGTCAGCCAC3' \\
$\mathbf{A 0 4}$ & 5'AATCGGGCTG3' \\
$\mathbf{A 0 5}$ & 5'AGGGGTCTTG3' \\
$\mathbf{A 0 6}$ & 5'GGTCCCTGAC3' \\
$\mathbf{A 0 7}$ & 5'GAAACGGGTG3' \\
$\mathbf{A 0 8}$ & 5'GTGACGTAGG3' \\
$\mathbf{A 0 9}$ & 5'GGGTAACGCC3' \\
$\mathbf{A 1 0}$ & 5'GTGATCGCAG3' \\
\hline
\end{tabular}

The PCR reaction were carried out in $50 \mu \mathrm{L}$ volumes tubes containing $100 \mathrm{ng}$ of genomic DNA, 10 $\mu \mathrm{M}$ of each primer, $200 \mu \mathrm{M}$ of dATP, dDTP, dCTP, dGTP, 10 mMTris-HCL, $\mathrm{pH} 8.3,50 \mathrm{mM} \mathrm{MgCl}_{2}$ and $0.001 \%$ gelatin. The Taq DNA polymerase (Promega, Corporation, Madison, WI) concentration was 1.5 units per assay. The PCR reaction was conducted using Eppendorf thermocycler programmed according to the following protocol that consisted of $1 \mathrm{~min}$. at $95 \mathrm{C}^{\circ}$ followed by 55 cycles of $20 \mathrm{sec}$. at $94^{\circ} \mathrm{C}, 30 \mathrm{sec}$. at $37^{\circ} \mathrm{C}$, and $2 \mathrm{~min}$. at $72^{\circ} \mathrm{C}$ as described by Nadig et al. (1998). Amplification products were electrophoresed in $1.5 \%$ Agarose gel in 1 x TAE buffer, stained with ethidium bromide and visualized with UV transilluminator and photographed- A1000 bp ladder (Promega, Corporation, Madison, WI) was loaded on the gel for calculation of fragment size.

\section{Statistical analysis}

The results were subjected to Duncan's multiple range test for comparing the sixteen treatment combination at a significance level $(\alpha=0.05)$. Calculations were carried out using the software package Statistica $^{\mathrm{TM}}$ for Windows version 6.1 (Statsoft Inc., 2001).

\section{RESULTS AND DISCUSSION}

\section{Broccoli yield}

Yield is the most important trait and the ultimate goal for production process. Increase in the crop yield can come from a variety of sources, such as increased genetic yield potential, improved agronomic practices, better adaptation to environmental conditions, greater resistance to pests and diseases and interactions between all these sources (Gifford and Evans, 1981).

The larger size culture bags showed higher performance in both plant and curd fresh and dry weight in both genotypes (Table 2). The reduction due to the smaller size container were $65.8 \%$ in "Sultan" cv. and $62.5 \%$ in "Marathon" cv. and this may be explained by the adverse effects of restricted culture container on plant growth and yield (White, 1980; Peterson et al., 1991). The reduction was more pronounced in the smaller size container under salinity treatment compared with non-saline treatment (Table 2). This may be caused by the dilution effect of salty solution that occurs with larger size containers. Salinity treatment negatively affected the growth and yield of broccoli plants in both genotypes. The reduction in yield was $55.6 \%$ in "Sultan" cv. while the percentage reached $57.4 \%$ in "Marathon" cv. (Table 2).

Unexpectedly, in most cases sulfur treatments did not improve growth and yield neither in saline nor in non-saline treatments, except in non-saline treatment of "Marathon" cv. where the increase due to sulfur was pronounced $(38.6 \%)$. This may be due to the low concentration of sulfur added to each treatment in current experiment (only 3 g per each liter of soil), and the positive effect of sulfur on broccoli yield described in the literature can be achieved by using sufficiently higher amount of soil-applied sulfur.

Sulfur is an essential nutrient for plants and plays an important role in their life. Sulfur deficiency inhibits the growth and development of plants and considerably reduces crop yields. Sulfur is a constituent of amino acids, such as methionine, cystine and cystein which are essential components of protein molecules. Sulfur is also present in vitamins, such as thiamine and biotin which play an important role in plant metabolism. Thiamine is a constituent of some enzymes catalyzing decarboxylation of organic and amino acids while biotin takes part in deamination and decarboxylation of certain amino acids. Consequently, sulfur plays a major role in carbohydrate and nitrogen metabolism in plants (Yagodin, 1984). In addition, sulfur is a component of glucosinolates, which are characteristics secondary metabolites in Brassica (Mithen et al., 2000). The term Sulfur Induced Resistance (SIR) denotes the reinforcement of the natural resistance of plants to fungal pathogens by stimulating the metabolic processes involving sulfur through targeted sulfate-based and soilapplied fertilizer strategies (Haneklaus et al., 2006).

The amino acids cysteine and methionine are the major end-products of sulfate assimilation in plants. Cysteine is the basic compound for other sulfur metabolites such as glutathione (GSH), glucosinolates (GSL), phytoalexins, pathogenesis related (PR) proteins and $\mathrm{H}_{2} \mathrm{~S}$. All of these compounds are linked to resistance mechanisms of plants. Cysteine is the first major sulfur compound, itself showing fungicidal effects (Vidhyasekaran, 2000). $\mathrm{H}_{2} \mathrm{~S}$ may be released prior to or after cysteine formation. Commonly, $\mathrm{H}_{2} \mathrm{~S}$ is regarded as being fungitoxic.

During the hypersensitive response of plants after infection with pathogens $\mathrm{H}_{2} \mathrm{O}_{2}$ is released rapidly, which modifies cell metabolism in favor of phytoalexin and PR-protein accumulation, and finally results in programmed cell death (Foyer and Rennenberg, 2000; Hammerschmidt and Nicholson, 2000). GSH seems to 
be involved in cell wall reinforcement (Gullner and Komives, 2001) and is coupled to high ascorbic acid which is related to resistance against fungal pathogens (Vidhyasekaran, 2000). Phytoalexins as a means of induced disease resistance include PR-proteins, lowmolecular weight antibiotics Glucosinolates are characteristic sulfur-containing secondary compounds of Brassica crops that act as phytoanticipins.
Sulfur-containing compounds play an important role in plant stress defense. Both glutathione and cysteine contents are found to increase under salt stress and glutathione may play a protective role against salinity stress in plants. Cysteine is incorporated into glutathione that is one of the major redox controllers and plays significant roles in scavenging ROS.

Table (2): Interaction effect of genotype, salinity, sulfur and container size on broccoli growth and yield

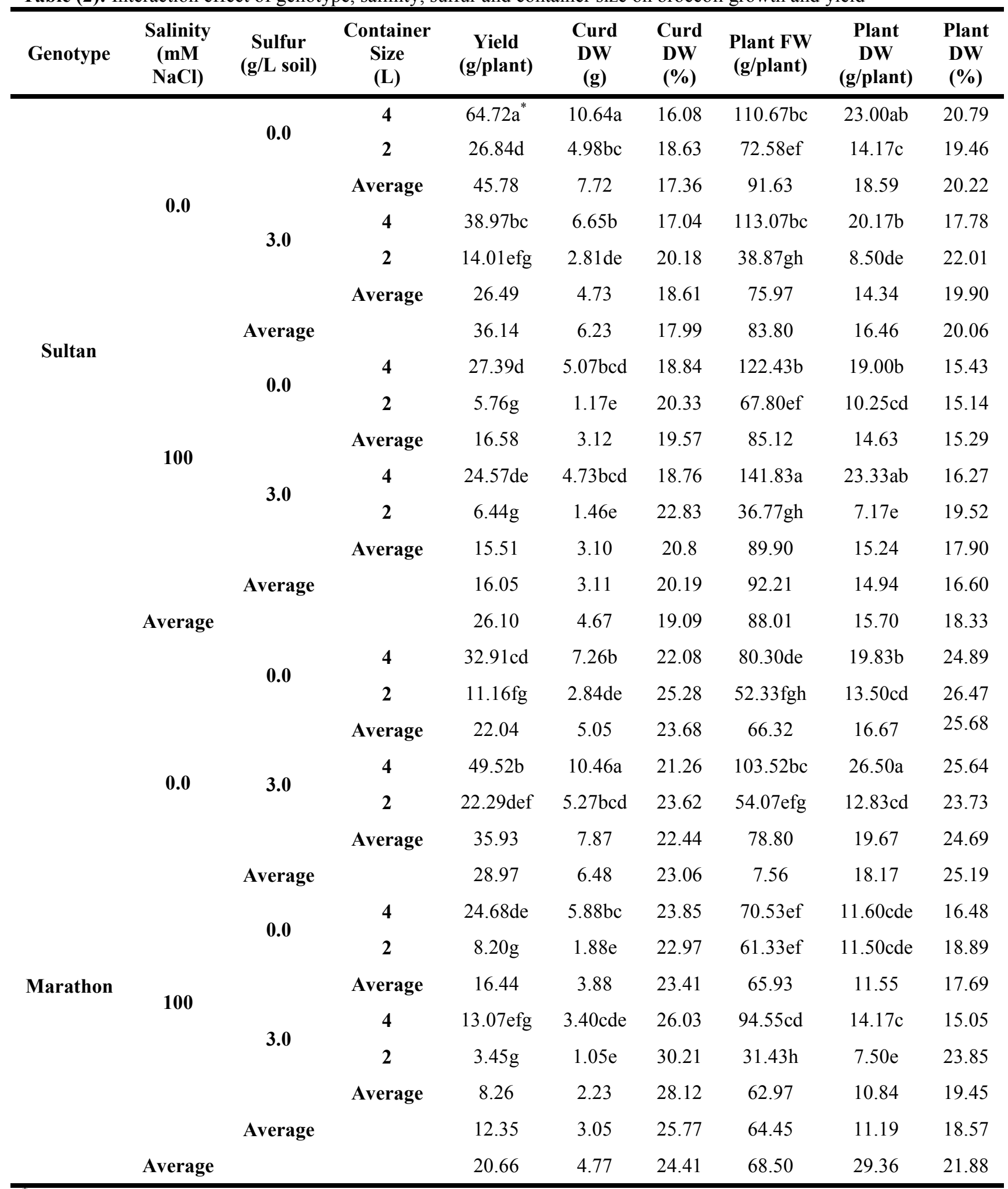


The sulfur response genes involved in sulfate transport and assimilation or in related metabolisms induced under different stress conditions, suggesting the existence of a general adaptive response to an increased in the cell demand for reduced sulfur (Nikiforova et al., 2003). These genes definitely were different in the two tested broccoli genotypes in the current study and this might explain the diverse performance between the two genotypes concerning disease infection. In addition, "Marathon" and "Sultan" cvs. have shown a significantly different performance regarding yield, nitrate and vitamin $\mathrm{C}$ content as well as response to sulfur application (Abd El-Hamed and Elwan, 2010, 2013; Elwan and Abd El-Hamed, 2011).

Further analysis was carried out to apply molecular tools to assess the polymorphism existed as well as discriminate between the two broccoli genotypes. Ten primers which produced good and reproducible polymorphic bands among the two genotypes have been used. Higher number of amplified bands is offering an excellent chance for detecting DNA polymorphisms among individuals (Williams et al., 1990). The presence of unique bands indicates that each genotype had one or more novel sequences which were not found in the other genotype. Unique bands are very useful for genotype identification to differentiate specific genotype from others (Vishwanath et al., 2010).

RAPD PCR analysis showed promising results concerning the decrementing between both genotypes. Primers showed high degree of polymorphism between the two genotypes (Figure 1). Several unique bands in only one genotype have been detected suggesting a high degree of genetic variation between the two genotypes. The analysis resulted in 14 unique bands in both genotypes out of the total 46 produced bands (Table 3 ) (Figure 1). "Sultan" cv. created 5 unique bands out of the total 37 produced bands while "Marathon" cv. created 9 unique bands out of the total 41 produced bands. Polymorphism level was different from one primer to the other. Primers A05, A07, and A08 were specific for "Sultan" cv., while primers A02 and A04 were specific to "Marathon" cv. Primer A07 produced the highest number of unique bands in "Sultan" cv. (3 bands), however, primer A04 gave the highest number of unique bands in "Marathon" cv. (7 bands) (Table 3) (Figure 1).

Table (3): Primers with arbitrary sequence tested for their effectiveness in the RAPD-PCR analysis that produced polymorphic bands in two broccoli genotypes

\begin{tabular}{|c|c|c|c|c|c|c|}
\hline \multirow{2}{*}{ Primers } & \multicolumn{2}{|c|}{ Sultan } & \multicolumn{2}{|c|}{ Marathon } & \multicolumn{2}{|c|}{ Polymorphism } \\
\hline & No. of Bands & Unique Bands & No. of Bands & Unique Bands & No. & $\%$ \\
\hline A01 & 5 & 0 & 5 & 0 & $0 / 5$ & $0 \%$ \\
\hline A02 & 0 & 0 & 2 & 2 & $2 / 2$ & $100 \%$ \\
\hline A03 & 6 & 0 & 6 & 0 & $0 / 6$ & $0 \%$ \\
\hline A04 & 1 & 0 & 8 & 7 & $7 / 8$ & $87.5 \%$ \\
\hline A05 & 1 & 1 & 0 & 0 & $1 / 1$ & $100 \%$ \\
\hline A06 & 8 & 0 & 8 & 0 & $0 / 8$ & $0 \%$ \\
\hline A07 & 7 & 1 & 6 & 0 & $1 / 7$ & $14.3 \%$ \\
\hline A08 & 3 & 3 & 0 & 0 & $3 / 3$ & $100 \%$ \\
\hline A09 & 6 & 0 & 6 & 0 & $0 / 6$ & $0 \%$ \\
\hline A10 & 0 & 0 & 0 & 0 & $0 / 0$ & $0 \%$ \\
\hline Total & 37 & 5 & 41 & 9 & $14 / 46$ & $30.4 \%$ \\
\hline
\end{tabular}




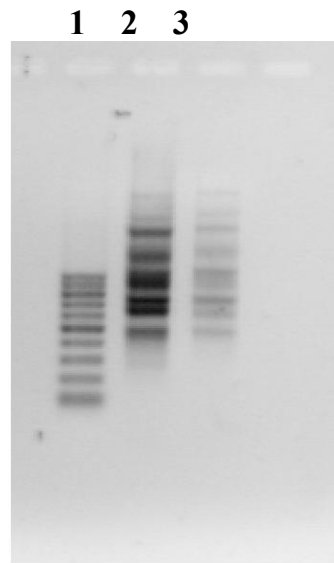

Primer 1

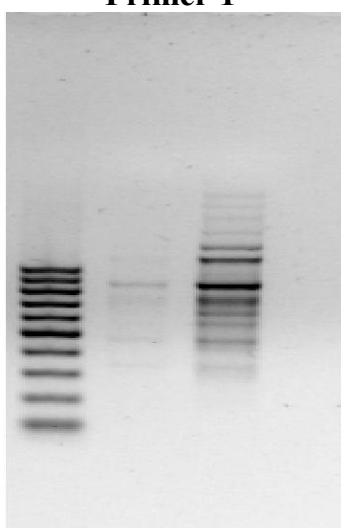

Primer 4

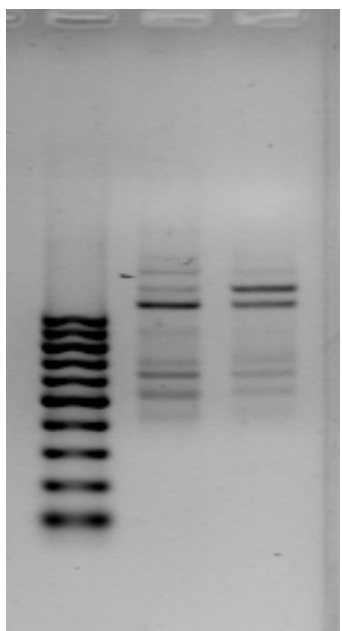

Primer 7
123

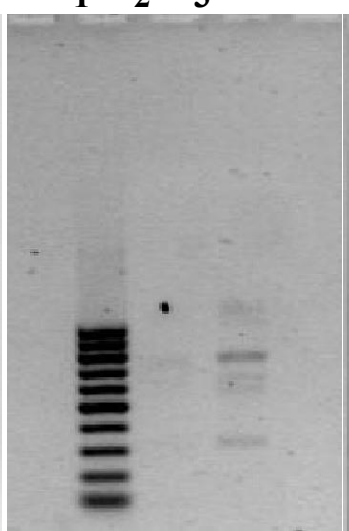

1223

Primer 2

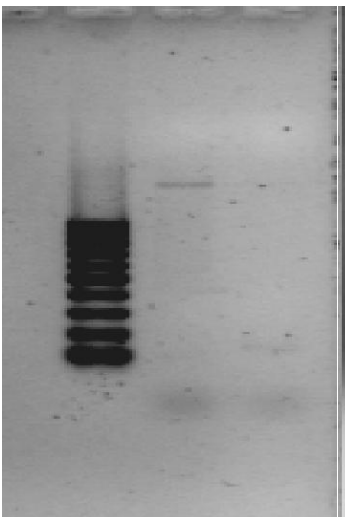

Primer 5

Primer 6
Primer 3

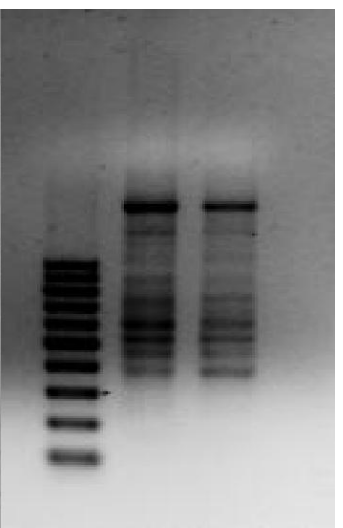

Figure (1): RAPD-PCR polymorphism of two broccoli genotypes using 10 primers (1- 1 kb DNA ladder; 2- "Sultan"; 3- "Marathon") (primer 10 was not shown)

Genotypes "Sultan" and "Marathon" showed considerably different performance regarding both gray mold and salinity tolerance. "Sultan" cv. was more resistant to grey mold compared to "Marathon" $\mathrm{cv}$. and also was less affected by salinity. On the other hand, RAPD analysis identified number of unique bands to each genotype (Table 3) (Figure 1). Consequently, we may speculate that the specific bands identified in genotype "Sultan" are responsible for its tolerance to biotic and abiotic stresses exist in this experiment. Further genetic analysis might be able to show linkage between these specific marker sequence and tolerant genes (Avila et al., 2003; Li and McVetty, 2013).
Tight linkage between molecular markers and genes for disease resistance can be of great benefit to disease resistance breeding programs by allowing following the DNA markers through the generations rather than waiting for phenotypic expression of the resistance genes. Once a gene has been found to be linked to markers, plants carrying the resistance gene can be easily identified (Lefebvre and Chèvre, 1995).

Interaction effect of genotype, salinity and sulfur treatment, container size on disease

As shown in Tables (4 and 5) and Figure (2), salinity treatment significantly increased the disease 
severity (DS) value by an average of $15.6 \%$ as compared to the control for genotype "Marathon" grown in small containers and $21.2 \%$ for the same genotype grown in large containers. These results agree with Tzortzakis (2009) who reported that salinity induced severity of gray mold [Botrytis cinerea (De Bary) Whetzel] in lettuce (Lactuca sativa L. cvs. "Beta" and "Paris Island"). Cantrell and Linderman (2001) indicated that pre-inoculation of transplants with vesicular-arbuscular mycorrhizal fungi can help alleviate deleterious effects of saline soils on crop yield. Sulfur treatment was the most effective treatment in decreasing DS by $100 \%$ for both genotypes grown in small and large containers. The combination of salinity and sulfur treatment decreased DS by $100 \%$ for genotype "Sultan" grown in both container sizes when compared to the control, while it decreased the DS for genotype "Marathon" with an average of $52.5 \%$.

Table (4): Pathogenicity test of Botrytis cinerea using leaves inoculation on genotypes "Marathon" and "Sultan"

\begin{tabular}{llc}
\hline \multirow{2}{*}{ Genotype } & \multicolumn{2}{c}{ Lesion length $(\mathbf{m m})}$. \\
\cline { 2 - 3 } & $\mathbf{2 4 h .}$ & $\mathbf{7 2 h}$. \\
\hline Marathon & 5.44 & 6.18 \\
Sultan & 0.11 & 0.11 \\
\hline
\end{tabular}

Based on pathogenicity test, "Marathon" cv. was a highly susceptible genotype with 5.4 and $6.2 \mathrm{~mm}$ of lesion length after 24 and 72 hours, respectively.
However, "Sultan" cv. was resistant genotype with lowest lesion length values of $0.11 \mathrm{~mm}$ (Table 4). Disease severity results showed also that "Marathon" cv. was highly susceptible genotype as compared to the "Sultan" cv. which was more resistant genotype. On the other hand, there was a relationship between the containers size and the severity of infection (the small containers showed high DS than that of large containers) and this may be due to the dilution effect of the salinity in large containers.

It is clear that sulfur treatment induced high plant resistance to grey mold in current study. Sulfurinduced resistance is the reinforcement of the natural resistance of plants against fungal pathogens through triggering the stimulation of metabolic processes involving sulfur. Sulfur is an essential macroelement for plant life and has numerous biological functions (Leustek et al., 2000; Marschner, 1995). Soil-applied sulfur fertilization proved to significantly reduce infection rate and severity of fungal diseases. The potential efficacy of so-called Sulfur Induced Resistance (SIR) expressed as a reduction of the disease index was found to range from $5-50 \%$ and $17-35 \%$ in greenhouse and field, respectively (Haneklaus et al., 2006). The metabolic pathway involved in SIR was suggested to involve the synthesis of phytoalexins, glutathione, glucosinolate and the release of sulfurcontaining volatiles (Haneklaus et al., 2006). Though the fungicidal effect of foliar applied elemental sulfur is known for a long time, it is a relatively new discovery that soil-applied sulfur in the form of sulfate can also have a positive effect on plant health (Haneklaus et al., 2002).

Table (5): Interaction effect of genotype, salinity, sulfur treatment and container size on the control of grey mold in broccoli caused by $B$. cinerea under greenhouse conditions

\begin{tabular}{lcccc}
\hline \multirow{2}{*}{ Treatment } & \multicolumn{2}{c}{$\mathbf{D S}^{*}($ Small containers) } & \multicolumn{2}{c}{ DS* (Large containers) } \\
\cline { 2 - 5 } & Marathon & Sultan & Marathon & Sultan \\
\hline Salinity & 3.26 & 0.48 & 2.52 & 0.38 \\
Sulfur & 0.00 & 0.00 & 0.00 & 0.00 \\
Salinity - Sulfur & 1.34 & 0.00 & 1.18 & 0.00 \\
Control & 2.82 & 0.44 & 2.08 & 0.28 \\
\hline
\end{tabular}

$\mathrm{DS}=$ Disease Severity
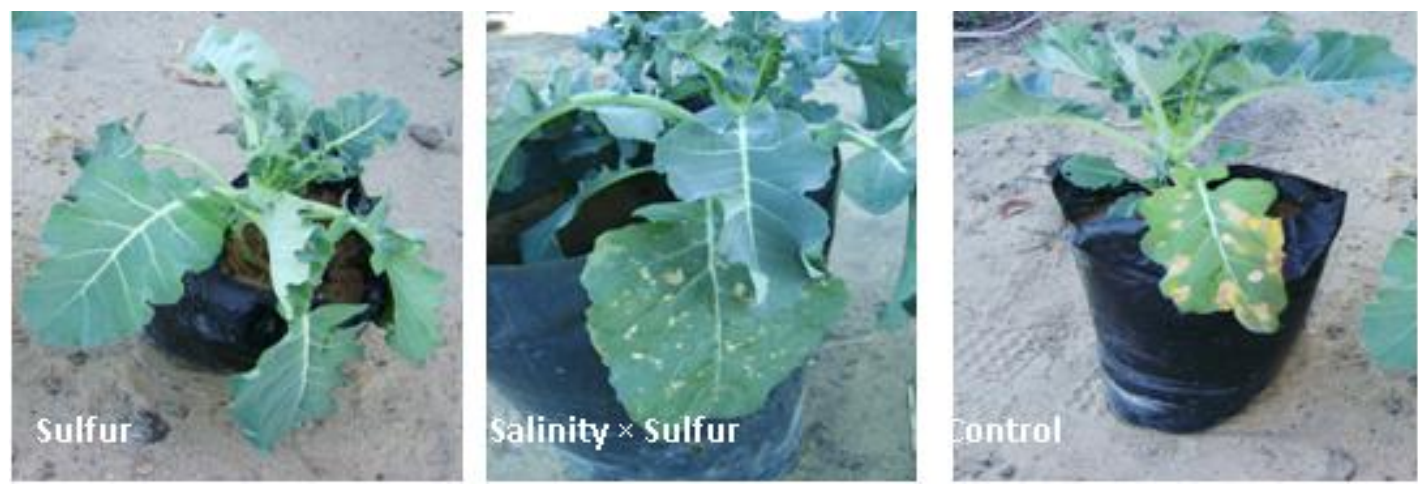

Figure (2): Interaction effect of salinity and sulfur treatment on the control of grey mold in broccoli caused by $B$. cinerea. 
It is suggested that salinity increase the DS due to the stress potential on the growing plants as reported in previous studies (Besri, 1993; Nachmias et al., 1993). Salinity stress can increase disease severity through inhibition of host normal defense mechanism (Blaker and MacDonalds, 1986; MacDonalds, 1984). The physiological processes that are activated in plant tissues following pathogen invasion, which serve to limit pathogen establishment or spread, also may be impaired by salinity stress. Salinity also prevents the plant from absorbing water efficiently, forcing it to use more energy to hydrate itself and further weakening the plant. Poor water intake reduces shoot growth and causes diseases. The incorporation of sulfur into saline soil decreased the DS in both genotypes because of the major role of sulfur in control of foliar diseases as mentioned above.

\section{Effect of propolis extract against Botrytis cinerea}

The inhibitory effect of different concentrations of propolis extract was tested on the growth and sclerotia germination of $B$. cinerea (Tables 6 and 7). Propolis extract at concentrations of $0.1 \%$ and $0.2 \%$ had less effect on the mycelial growth of $B$. cinerea as the causal organism of grey mold in broccoli. However, all the concentrations showed inhibitory effect (about $31.63 \%$ ) against $B$. cinerea until six days of incubation, inhibitory activity was partly increased on seven days of incubation. This increasing varied accordance to dose, effective material amount, effective level and fungus. However, the concentration of $0.3 \%$ of propolis showed higher inhibitory effect $(81.83 \%)$ after 7 days of incubation in comparison with other concentrations. On the other hand, all propolis concentrations reduced the germination of the sclerotia, while the most effective concentration was $0.3 \%$ as it reduced the germination of sclerotia approximately (26.67\%). Plant species used by bees as propolis source showed differences from region to region (Konig, 1985). Also, while propolis collected by bees grown in different regions showed similar properties due to some components, they showed highly different properties because of other components (Marletto, 1984). Only pinobanksin-3-acetate, 3-acetylpinobanksin, pinocembrin, p-coumaric acid and caffeic acid out of 26 or more components isolated propolis extract showed considerably antimycotinic effect (Ghisalberti, 1979). However, the same researcher reported that caffeic acid from propolis showed fungistatic effect against Helminthosponum carbonum. Lindenfelser (1967) reported that propolis inhibited the growth of 20 fungi among 39 isolated fungi samples. It was established that caffeic acid, benzyl cumarete, pinobanksin and pinocembrin found in propolis showed antimycotic properties. Yang et al. (2010) reported that Chinese propolis strongly inhibited mycelia growth and induced hyphae prominent abnormal morphological alterations of Penicillium digitatum and Penicillium italicum the causal organisms of green and blue mold of citrus, respectively. Also, Chinese propolis had strong detrimental effect on spore germination of the tested pathogens. Ozcan (1999) established that propolis known as balsam matter which collected by bees from several plants showed antifungal effect.

Table (6): The inhibitory effect of propolis extract against Botrytis cinerea the causal organism of broccoli grey mold

\begin{tabular}{lcc}
\hline Days & $\begin{array}{c}\text { Propolis Extract } \\
\text { Concentration (\%) }\end{array}$ & $\begin{array}{c}\text { Inhibition } \\
\text { Effect (\%) }\end{array}$ \\
\hline 3 & 0.1 & 31.40 \\
& 0.2 & 45.84 \\
& 0.3 & 47.50 \\
& 0.1 & 32.00 \\
$\mathbf{4}$ & 0.2 & 46.23 \\
& 0.3 & 50.93 \\
$\mathbf{5}$ & 0.1 & 33.57 \\
& 0.2 & 48.64 \\
& 0.3 & 57.60 \\
$\mathbf{6}$ & 0.1 & 42.00 \\
& 0.2 & 49.97 \\
& 0.3 & 63.67 \\
7 & 0.1 & 43.07 \\
& 0.2 & 63.73 \\
& 0.3 & 81.83 \\
\hline
\end{tabular}

Table (7): Effect of propolis extract on the germination of sclerotia of $B$. cinerea in broccoli.

\begin{tabular}{lc}
\hline $\begin{array}{l}\text { Propolis Extract } \\
\text { Concentration \% \% }\end{array}$ & $\begin{array}{c}\text { \% Sclerotia } \\
\text { Germination }\end{array}$ \\
\hline $\mathbf{0 . 0}$ & 100.0 \\
$\mathbf{0 . 1}$ & 86.67 \\
$\mathbf{0 . 2}$ & 63.34 \\
$\mathbf{0 . 3}$ & 26.67 \\
\hline
\end{tabular}

\section{CONCLUSION}

Salinity treatment negatively affected the growth and yield of broccoli in both genotypes and sulfur treatments were not able to alleviate the adverse effects of salinity on broccoli plants. Resistance of broccoli to the gray mold was genotype dependent. Salinity treatment significantly increased the disease severest. Sulfur was the most effective treatment in decreasing the disease severity. Propolis extract showed inhibitory effect on infection with Botrytis in broccoli and can be recommend as an environment-friendly mean of disease control. For promoting resistance mechanisms, sulfur supply which only covers metabolic needs, is apparently not sufficient. A constantly high plant available sulfur reserve in the soil might also be required to satisfy the enhanced sulfur demand for plant defense during infection by fungal pathogens. Genetic differences between the two broccoli genotypes were obvious by RAPD analysis. 


\section{REFERENCES}

Abd El-Hamed, K. E. and M. W. M. Elwan (2010). Genotype by environment interaction and phenotypic stability of yield and quality in broccoli (Brassica oleracea var. italica). Journal of Plant Production, Mansoura University, 1 (6): 819-835.

Abd El-Hamed, K. E. and M. W. M. Elwan (2013). Broccoli yield and yield efficiency in correlation with photosynthetic pigments. Hortscience Journal of Suez Canal University, 1: 69-76.

Agnola, B., D. Silue and S. Boury (2000). Identification of RAPD markers of downy mildew (Peronospora parasitica) resistance gene in broccoli (Brassica oleracea var. italica). In: King G.J. (ed.) Proceedings of the $3^{\text {rd }}$ ISHS international symposium on Brassicas, Horticulture Research International, Wellesbourne, p.64.

Ashraf, M. (2009). Biotechnological approach of improving plant salt tolerance using antioxidants as markers. Biotechnol. Adv., 27: 84-93.

Avila, C. M., J. C. Sillero, D. Rubiales, M. T. Moreno and A. M. Torres (2003). Identification of RAPD markers linked to the Uvf-1 gene conferring hypersensitive resistance against rust (Uromyces viciae-fabae) in Vicia faba L. Theoretical and Applied Genetics, 107(2): 353-358.

Bernardo Royo, J. and R. Itoiz (2004). Evaluation of the discriminance capacity of RAPD, isoenzymes and morphologic markers in apple (Malus $\mathrm{x}$ domestica Borkh.) and the congruence among classifications. Genet. Resour. Crop Evol., 51: 153-160.

Besri, M. (1993). Effects of salinity on plant diseases development. In: Towards the Rational Use of High Salinity Tolerant Plants. Lieth, $\mathrm{H}$. and $\mathrm{Al}$ Masoom, A.A. (eds.), Volume 28, Part 1, 6774.

Biswas, B. C. and R. K. Tewatia (1991). Role of sulphur in balanced plant nutrition: Indian experience. In: S. Portch (ed.): Proceedings of the International Symposium on the Role of Sulphur, Magnesium and Micronutrients in Balanced Plant Nutrition. The Potash and Phosphate Institute of Canada, 98-106.

Blaker, N. S. and J. D. MacDonald (1986). The role of salinity in the development of phytophthora root rot of citrus. Phytopathology, 76: 970-975.

Bourbos, V. A., M. T. Skoudridakis, E. Barbopoulou and K. Venetis (2000). Ecological control of grape powdery mildew (Uncinula necator). (Http://www.landwirtschaft-mlr.badenwuerttemberg.de/la/lvwo/kongress/SULFUR.ht $\mathrm{ml})$.

Bussey, M. J. and W. R. Stevenson (1991). A leaf disk assay for detecting resistance to early blight caused by Alternaria solani in juvenile potato plants. Plant Disease, 75: 385-390.
Cansian, R. L. and S. Echeverrigaray (2000). Discrimination among cultivars of cabbage using randomly amplified polymorphic DNA markers. HortScience, 35(6): 1155-1158.

Cantrell, I. C. and R. G. Linderman (2001). Preinoculation of lettuce and onion with VA mycorrhizal fungi reduces deleterious effects of soil salinity. Plant and Soil, 233: 269-281.

Chen, Y. and D. Wang (2005). Two convenient methods to evaluate soybean for resistance to Sclerotinia sclerotiorum. Plant Disease, 89(12): 1268-1272.

Cherbuliez, T. (1996). Bee venom therapy- A review. International Conference on: Bee Products: properties, applications and apitherapy pp: 54, Israel.

Crane, E. (1990). Bees and Beekeeping Science Practice and World Resources. Heinemann Professional Publishing Ltd. Oxford.

Deans, S. G. and K. P. Svoboda (1990). The antimicrobial properties of marjoram (Origanum majorana L.) volatile oil. Flavour and Fragrance Journal, 5(3): 187-190.

Donini, P., R. J. Cooke and J. C. Reeves (2000). Molecular markers in variety and seed testing. Plant Genetic Engineering: Towards the Third Millennium, Developments in Plant Genetic and Breeding, 5: 27-34.

Elad, Y., B. Williamson, P. Tudzynski and N. Delen (2007). Botrytis spp. and diseases they cause in agricultural systems - an introduction. pp. 1-24. In: Elad, Y., Williamson, B., Tudzynski, P., Delen, N. (eds), Botrytis: Biology, Pathology and Control. Springer, 1-8.

Ellis, M. B. (1971). Dematiaceous hyphomycetes. Commonwealth Mycological Institute. Kew, Surrey, England. 608 pp.

Elwan, M. W. M. and K. E. Abd El-Hamed (2011). Influence of nitrogen form, growing season and sulfur fertilization on yield and the content of nitrate and vitamin $\mathrm{C}$ in broccoli. Scientia Horticulturae, 127: 181-187.

Eriksen, J., K. Thorup-Kristensen and M. Askegaard (2004). Plant availability of catch crop sulfur following spring incorporation. Journal of Plant Nutrition and Soil Science, 167(5): 609615.

Evans, D. A., W. R. Sharp and H. P. Medina-Filho (1984). Somaclonal and gametoclonal variation. Am. J. Bot., 71: 759-774.

Fahey, J. W., A. T. Zalcmann and P. Talalay (2002). The chemical diversity and distribution of glucosinolates and isothiocyanates among plants. Phytochemistry, 56(1): 5-51.

Farinhó, M. J., P. S. Coelho, A. A. Monteiro and J. M. Leitão (2000). RAPD and AFLP markers linked to Peronospora parasitica resistance genes in broccoli. In: King G.J. (ed.) Proceedings of the $3^{\text {rd }}$ ISHS International Symposium on Brassicas, Horticulture Research International, Wellesbourne, p.75.

Feraboli, F. (1996). Apitherapy in Orthopaedic Diseases. International Conference on: Bee 
Products: properties, applications and apitherapy. P: 55, Israel.

Foyer, C. H. and H. Rennenberg (2000). Regulation of glutathione synthesis and its role in abiotic and biotic stress defense. In: C. Brunold, $\mathrm{H}$. Rennenberg, L. J. De Kok, I. Stulen and J. C. Davidian (eds.). Sulfur Nutrition and Sulfur Assimilation in Higher Plants, pp. 127-153. Berne: Paul Haupt Publishers.

Ghisalberti, E. L. (1979). Propolis: A review. Bee World, 60: 59-84.

Gifford, R. M. and L. T. Evans (1981). Photosynthesis, carbon partitioning, and yield. Annual Review of Plant Physiology, 32(1): 485-509.

Giovannelli, J. L., M. W. Farnham, M. Wang and A. E. Strand (2002). Development of sequence characterized amplified region markers linked to downy mildew resistance in broccoli. Journal of the American Society for Horticultural Science, 127(4): 597-601.

Grange, J. M. and R. W. Davey (1990). Antibacterial properties of propolis (bee glue). J. Royal. Soc. Med., 83: 159-160.

Gullner, G. and T. Komives (2001). The role of glutathione and glutathione-related enzymes in plant pathogen interactions. In Significance of Glutathione in Plant Adaptation to the Environment, pp. 202-239. Eds. D. Grill, M. Tausz and L.J. De Kok, Dordrecht: Kluwer Academic Publishers.

Hale, A. L., M. W. Farnham and M. A. Menz (2006). Use of PCR-based markers for differentiating elite broccoli inbreds. Journal of the American Society for Horticultural Science, 131(3): 418423.

Hammerschmidt, R. and R. L. Nicholson (2000). A survey of plant defense responses to pathogens. In: A.A. Agrawal, S. Tuzun and E. Bent (eds.). Induced Plant Defenses against Pathogens and Herbivores, pp. 55-71. St. Paul, MN: APS Press.

Haneklaus, S., E. Bloem and E. Schnug (2002). The significance of sulphur induced resistance (SIR) for sustainable agricultural production systems. $13^{\text {th }}$ International Reinhardsbrunn Symposium "Modern Fungicides and Antifungal Compounds", 14-18 May 2001, Friedrichroda, Germany. pp: 365-371.

Haneklaus, S., E. Bloem and E. Schnug (2006). Disease control by sulphur induced resistance. Aspects of Applied Biology, 79: 221-224.

Hasegawa, P. M., R. A. Bressan, J. K. Zhu and H. J. Bohnert (2000). Plant cellular and molecular responses to high salinity. Annual Review of Plant Biology, 51(1): 463-499.

$\mathrm{Hu}$, J. and C. F. Quiros (1991). Identification of broccoli and cauliflower cultivars with RAPD markers. Plant Cell Reports, 10(10): 505-511.

Jarvis, W. R. (1977). Botryotinia and Botrytis species: Taxonomy, Physiology and Pathogenicity. Monograph No. 15. A guide to the Literature. Department of Agriculture. Ottawa, Canada.
Kim, S-J., T. Matsuo, M. Watanabe and Y. Watanabe (2002). Effect of nitrogen and sulphur application on the glucosinolate content in vegetable turnip rape (Brassica rapa L.). Soil Sci. Plant Nutr., 48(1): 43-49.

Konig, B. (1985). Plant sources of propolis. Bee World. 66: 136-139.

Kurilich, A. C., G. J. Tsau, A. Brown, L. Howard, B. P. Klein, E. H. Jeffery, M. Kushad, M. A. Wallig and J. A. Juvik (1999). Carotene, tocopherol, and ascorbate contents in subspecies of Brassica oleracea. J. Agric. Food. Chem., 47: 1576-81.

Lee, D., J. C. Reeves and R. J. Cooke (1996). DNA profiling and plant variety registration: 1 . The use of random amplified DNA polymorphisms to discriminate between varieties of oilseed rape. Electrophoresis, 17(1): 261-265.

Lefebvre, V. and A. M. Chèvre (1995). Tools for marking plant disease and pest resistance genes. Agronomie, 15: 3-19.

Leustek, T., M. N. Martin, J. A. Bick and J. P. Davies (2000). Pathways and regulation of sulfur metabolism revealed through molecular and genetic studies. Annu. Rev. Plant Physiol. Plant Mol. Biol, 51: 141-65.

Li, G. and P. B. McVetty (2013). Genetics and gene mapping of disease resistance in Brassica. Translational Genomics for Crop Breeding: Biotic Stress, Volume 1: 327-344.

Lindenfelser, L. A. (1967). Antimicrobial activity of propolis. Am. Bee J. 107: 90-92.

MacDonald, J. D. (1984). Salinity effects on the susceptibility of chrysanthemum roots to Phytophthora cryptogea. Phytopathology, 74: 621-624.

Mailer, R. J. (1989). Effects of applied sulfur on glucosinolate and oil concentrations in the seeds of rape (Brassica napus L.) and turnip rape (Brassica rapa L. var. silvestris (Lam.) Briggs). Crop and Pasture Science, 40(3): 617624.

Marletto, F. (1984). Particularities of propolis depending on flower source and its utilization. Apiacta, 3: 71-74.

Marschner, H. (1995). Mineral Nutrition of Higher Plants, Academic Press, London.

Michelmore, R. (1995). Molecular approaches to manipulation of disease resistance genes. Annual Review of Phytopathology, 33(1): 393-427.

Mithen, R. (1992). Leaf glucosinolate profiles and their relationship to pest and disease resistance in oilseed rape. Euphytica, 63: 71-83.

Mithen, R. F., M. Dekker, R. Verkerk, S. Rabot and I. T. Johnson (2000). The nutritional significance, biosynthesis and bioavailability of glucosinolates in human foods. Journal of the Science of Food and Agriculture, 80(7): 967-984.

Moreno, D. A., M. Carvajal, C. López-Berenguer and C. García-Viguera (2006). Chemical and biological characterization of nutraceutical 
compounds of broccoli. Journal of Pharmaceutical and Biomedical Analysis, 41(5): 1508-1522.

Munns, R. and M. Tester (2008). Mechanisms of salinity tolerance. Annu. Rev. Plant Biol., 59: 651-681.

Murray, M. G. and W. F. Thompson (1980). Rapid isolation of high molecular weight plant DNA. Nucleic Acids Res., 8: 4321-4325.

Nachmias, A., Z. Kaufman, L. Livescu, L. Tsror, A. Meiri and P. D. S. Caligari (1993). Effects of salinity and its interactions with disease incidence on potatoes grown in hot climates. Phytoparasitica, 21(3): 245-255.

Nadig, S. G., K. L. Lee and S. M. Adams (1998). Evaluating alterations of genetic diversity in sunfish populations exposed to contaminants using RAPD assay. Aquatic Toxicology, 43(2): 163-178.

Nazar, R., N. Iqbal, A. Masood, S. Syeed and N. A. Khan (2011). Understanding the significance of sulfur in improving salinity tolerance in plants. Environmental Experimental Botany, 70: $80-87$

NeSmith, D. S. and J. R. Duval (1998). The effect of container size. HortTechnology, 8(4): 495-498.

Nicoforova, V., J. Freitag, S. Kempa, M. Adamik, H. Hesse and R. Hoefgen (2003). Transcriptome analysis of sulfur depletion in Arabidopsis thaliana: interacting of biosynthetic pathways provides response specificity. Plant J., 33: 633- 650.

Ozcan, M. (1999). Antifungal properties of propolis. Grasas y Aceites. 50 (5): 395-398.

Peterson, T. A., M. D. Reinsel and D. T. Krizek (1991). Tomato (Lycopersicon esculentum Mill., cv. 'Better Bush) plant response to root restriction. I. Alteration of plant morphology. J. Exp. Bot., 42: $1233-1240$

Rosa, E. A. S., R. K. Heaney, G. R. Fenwick and C. A. M. Portas (1997). Glucosinolates in crop plants. Horticultural Reviews, 19: 99-215.

Ruff, M. S., D. T. Krizek, R. M. Mirecki and D. W. Inouye (1987). Restricted root zone volume: Influence on growth and development of tomato. Journal of the American Society for Horticultural Science, 112(5): 763-769.

Scheller, S. (1990). Plant origins of propolis: A report of work at Oxford. Bee World, 30.

Schmidt, L. S. and J. O. Schmidt (1996). Medical overconcern; what are the real allergic and healthy risks from bee product and apitherapy. Int. Confer. Product: properties, applications and apitherapy, P: 43. Israel.

Statsoft, Inc. (2001). STATISTICA für Windows
[Software-system für Datenanalyse] Version 6. www. Statsoft.com.

Türkan, I. and T. Demiral (2009). Recent developments in understanding salinity tolerance. Environmental and Experimental Botany, 67(1): 2-9.

Tzortzakis, N. G. (2009). Alleviation of salinity-induced stress in lettuce growth by potassium sulphate using nutrient film technique. International Journal of Vegetable Science, 15(3): 226-239.

van Poppel, G., D. T. Verhoeven, H. Verhagen and R. A. Goldbohm (1999). Brassica vegetables and cancer prevention. Epidemiology and Mechanisms. Adv. Exp. Med. Biol., 472: 159168.

Vidhyasekaran, P. (2000). Physiology of Disease Resistance in Plants. Volume II. Boca Raton, FL: CRC Press, Inc.

Vishwanath, K., K. P. R. Prasanna, H. M. Pallvi, P. Rajendra, S. Ramegowda and P. J. Devaraju (2010). Identification of tomato (Lycopersicon esculentum) varieties through total soluble seed proteins. Research Journal of Agricultural Sciences, 2(1): 8-12.

Walker, P. and E. Crane (1987). Constituents propolis. Apidologie, 18: 327-334.

Waugh, R. (1997). RAPD analysis: use for genome characterization, tagging traits and mapping. In Plant Molecular Biology- A Laboratory Manual (pp. 305-333). Springer Berlin Heidelberg.

White, J. M. (1980). Cabbage yields, head weight, and size as affected by plant growing containers. Proc. Fla. State Hort. Soc., 93: 266-267.

Williams, J. G., A. P. Kubelik, K. J. Livak, J. A. Rafaski and S. V. Tingey (1990). DNA polymorphisms amplified by arbitrary primers are useful as genetic markers. Nucleic Acids Res., 18(22): 6531-6535.

Williamson, B., B. Tudzynski, P. Tudzynski and J. A. van Kan (2007). Botrytis cinerea: the cause of grey mould disease. Molecular Plant Pathology, 8(5): 561-580.

Yagodin, B. A. (1984). Agricultural Chemistry (Part 1). Mir Publishers, Moscow. pp. 375.

Yamauchi, R., K. Kato, S. Oida, J. Kanaeda and Y. Ueno (1992). Benzyl caffeate on antioxidative compound isolated from propolis. Bioscience, Biotechnology and Biochemistry, 56: 13211322.

Yang, S., L. Peng, Y. Cheng, F. Chen and S. Pan (2010). Control of citrus green and blue molds by Chinese propolis. Food Science and Biotechnology, 19 (5): 1303-1308. 


\section{تأثير التركيب الوراثي، الملوحة، المعاملة بالكبريت وحجم وعاء الزراعة على النمو والمحصول والإصابة

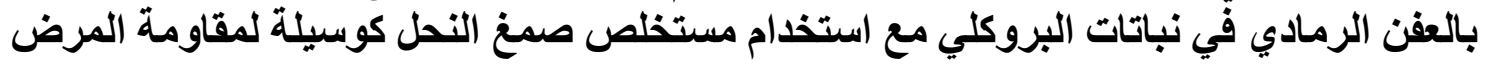

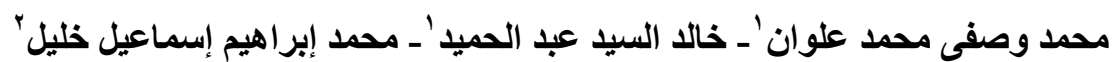

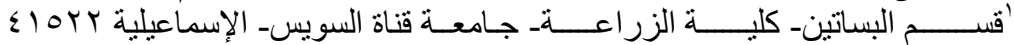

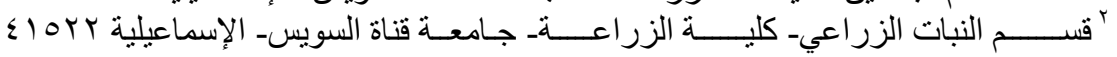

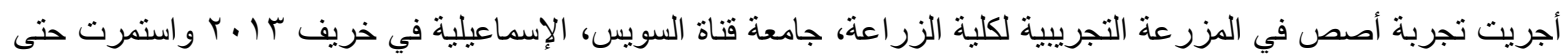

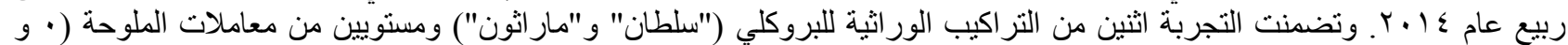

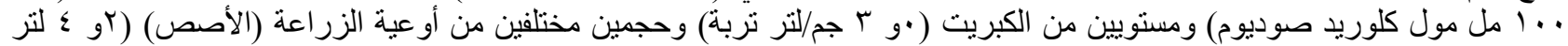

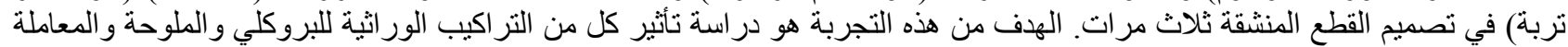

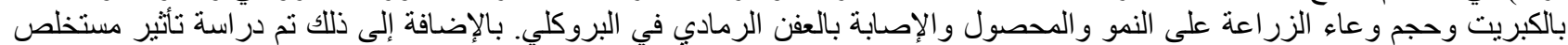

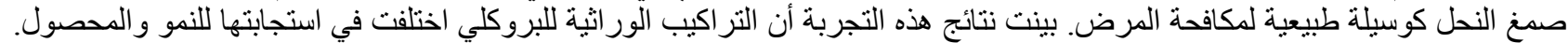

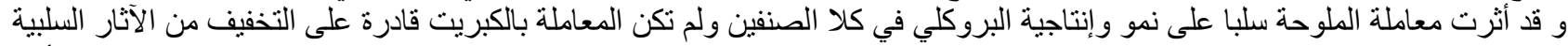

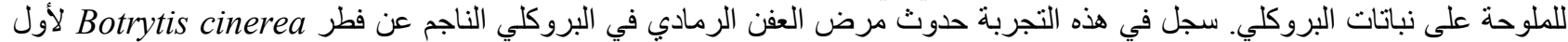

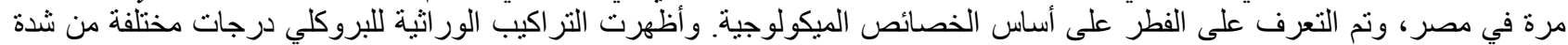

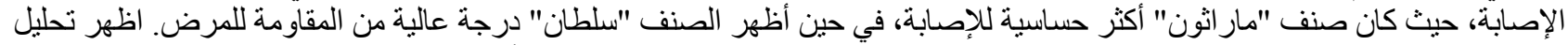

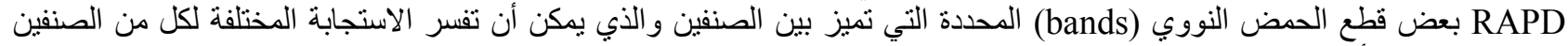

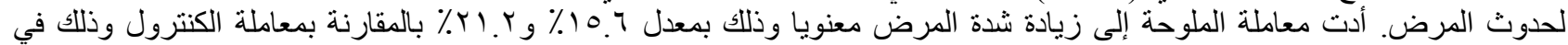

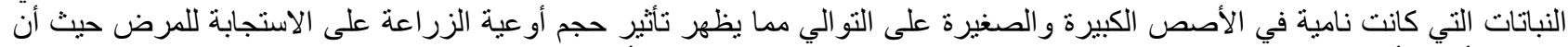

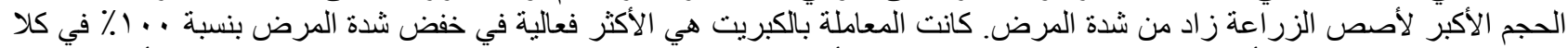

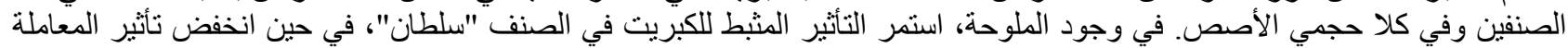

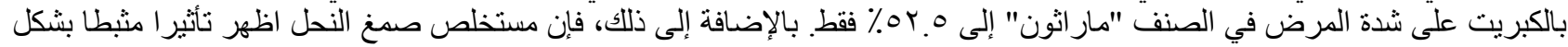

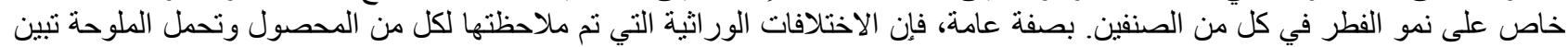

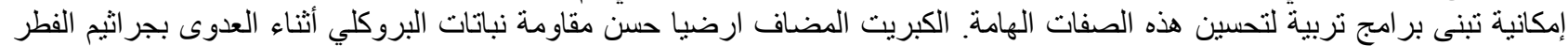

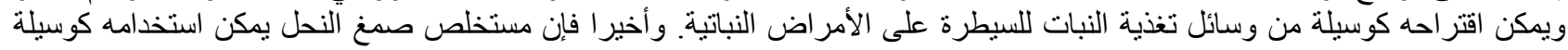
طبيعية لمقاومة مرض العفن الرمادي في البروكلي. 